\title{
ON THE BURNING OF COLONIAL COAL IN THE LOCOMOTIVES ON THE CAPE GOVERNMENT RAILWAYS.
}

By Mr. MiChate StePhens, Chief Locomotive Supgrintendent.

South African Coalfields.-The existence of Coal in South Africa was not generally known until within the last sixteen years; for although in 1864 an opening was made by Mr. George Vice into an outcrop at a place in the Stormberg mountains in the north-eastern part of the Cape Colony where the village of Molteno now standsas shown in the map of South Africa, Fig. 1, Plate 32,--the quantity extracted for many years afterwards was too small to attract notice, owing to the isolated position of the place and the poor quality of the coal near the outcrop; and it was not until the line known as the eastern system of the Cape Government Railways-from the port of East London to its former terminus at Queenstown, a distance of 151 miles-was under construction, that the possibility of working it with colonial coal received consideration. A mining engineer, Mr. F. W. North, was engaged to examine the colonial coalfields, and his report published in 1878 showed that the area of coal-bearing land was much greater than had been generally supposed. Boring operations undertaken by him to prove its extent were stopped by the outbreak of the Kaffir war in 1877-78; but fresh discoveries made between that date and the beginning of last year, partly on territory which at the cessation of the war in 1880 (Tembu rebellion) became government property, showed that the quantity of coal which can be made accessible by a branch railway from the eastern system will suffice for the requirements of the existing colonial railways at the present rate of consumption for about three centuries; whilst occasional outcrops in a north-easterly direction indicate the probability of the continuity of the coal beds through Pondoland to the borders of the colony of Natal. 
The existence of cxtensive coal beds in Natal of a rather better quality than any yet found in the Cape Colony has long been known; but owing to the absence of any local demand, and the prohibitory cost of transit by ox-wagon, they were almost unworked until recently, when the railway from the port of Durban was extended sufficiently near them to admit of a portion of the supply for the locomotives being conveyed to the line. An extension of the railway to the Transvaal border, now in progress, will admit of the coal being put direct into the trucks, when it is anticipated that the Natal Railways will be worked exclusively with local coal, and that the coasting steamers will also be supplied with it. Mr. William Milne, locomotive superintendent of the Natal Government Railways, considers that some descriptions of Natal coal are almost equal in steam generating properties to South Yorkshire coal, which was exclusively used formerly on the Natal Railways.

Outcrops of conl also occur in the Orange Free State and the native territory of Basutoland on the north-eastern border of the Cape Colony; but little is as yet known concerning them, with the exception of that at Kronstad in the north of the Free State, where an extensive coaltield exists, the working of which for the supply of the Kimberley diamond mines has recently been commenced; but, as in the case of the Cape and Natal coal, the operations are restricted by the cost of transport by ox-wagon. In the Transraal Republic, north of the Free State, the discoveries of gold, which have given such a remarkable impetus to the railway traffic and trade of South Africa generally, are rivalled by those of coal. Seams of from seqven to fourteen feet thickness, of both steam and bituminous coal, are being met with and worked to supply the extensive demand at the gold mines. Some of the Transvaal coal is superior in quality to any yet found in the Cape Colony, Natal, or the Orange Free State.

The total coal area of South Africa is thus summarised by Mr. W. Galloway of Cardiff, the mining engineer engaged by the Cape Government last year 1889 to make a special report on the Stormberg and Indwe coalfields in the eastern part of the Cape Colony, preparatory to the required connections being made for 
distributing the coal over the colonial railway system:- "The coalfield of South Africa covers a fairly symmetrical area, embracing parts of the Cape Colony, the Orange Free State, the Transvaal, Natal, and the whole of Basutoland.... The greatest length and breadth of the coalfield contained within this boundary line are 500 and 200 miles respectively, and its area is about 56,000 square miles. $\ldots$... $p$ to the present its fringe has just been touched in a few isolated and far-distant points; and it is certain that further systematic researches will be rewarded by the discovery of great stores of mineral fuel, capable of supplying the wants of South Africa for many generations."

Stormberg Mines.--The extension of the Eastern Railway, from the former terminus at Queenstown to the town of Aliwal North on the Orange River, passes through the Stormberg coalfield; and though, as regards the quality of the coal and cost of mining, the Indwe coalfield, 58 miles north-east of Queenstown, possesses great ndvantages over the Stormberg, the absence of railway communication has hitherto rendered it necessary that the supply for the working of the eastern system should be obtained from the two Stormberg mines known as the "Molteno" and the "Cyphergat." The Iatter mine, 204 miles north of the port of East London and 5,450 feet above sea-level, has the advantage of direct communication with the railway; the trams from the horizontal openings in the hill in which the coal is found are tipped upon the screens which deliver into the trucks; and the quality of the coal is rather better than the Molteno. The coal with which the eastern system has been worked for the last four years, to the exclusion of imported coal, has therefore been obtained mostly from the Cyphergat mine; and it is the mechanism employed in burning this coal which the present paper is intended to describe.

Coal Burning in Locomotives.-The Cyphergat coal is bituminous and gaseous, gives out a great heat, and generates steam rapidly as long as the grate is fairly clean; but it contains about 29 per cent. of incombustible matter, which becomes partially fused, and forms a 
pasty mass underneath the incandescent coal, and thus checks the generation of steam by preventing the admission of air between the fire-bars. Attempts were made to overcome the difficulty by means of tipping grates, rocking bars, and other contrivances; but these were not successful, and hand-labour was resorted to. The firemen were selected for strength and powers of endurance; the fire-bars were spaced 3 inches apart, that is with 3 inches clear open space between them, and the spaces were kept clear by pushing the semi-fused dross through them with the pricker. Owing to the gauge of the railway being 3 feet 6 inches, the narrowness of the fire-box renders the grate area sufficiently accessible for the purpose through a fire-hole of the ordinary size. The dross fell between the rails through openings in the ashpan; and as pieces of burning coal were pushed through with it, the progress of a train at night was marked by a streak of fire between the rails. Occasional halts had also to be made for removing through the fire-hole masses of dross which had become set; but apart from such delays the traffic was efficiently worked on a line abounding in gradients of 1 in 40 and five-chain curves. The work of the firemen however was exceptionally severe, being closely akin in that respect to puddling; and even the prospect of speedy promotion could hardly induee them to stop at it.

Movable-Bar Grate.-The difficulty has been overcome by the introduction of the movable-bar grate, which is the invention of Mr. J. D. Tilney, locomotive superintendent of the eastern system of the Cape Government Railways. In Figs. 3 and 4, Plates 33 and 34 , is shown its application to an outside-cylinder engine with six wheels coupled of 3 feet 6 inches diameter and a four-wheel bogie, and with cylinders 15 inches diameter and 20 inches stroke, and the ordinary link-motion: a type of engine much used on the Cape Railways, of which a general side elevation is shown in Fig. 2, Plate 33. The fire-bars, eleven in number, which are of cast-iron and spaced $1_{\frac{1}{2}}$ inches apart, rest on racks placed near their ends, and have serrated tops. The five alternate bars $B$ are $1 \frac{1}{2}$ inches shorter than the others, and have each a lug projecting downwards. A long 
pin goes through the lugs, and through the ends of two rods $R$ which pass from the pin through slots in the damper to the front axle, on which is fixed a drum D. The rods are connected to crankpins in another drum M, which the engine-driver can bring into contact with the drum on the axle by means of the hand lever $L$, as in the chain-brake arrangement. A longitudinal reciprocating motion of $1 \frac{1}{2}$ inches is thereby imparted through the rods to the five alternate bars $B$; and the dross which has settled on the serrations, being cooled by the air from below, is broken up when the bars are put in motion, and falls through doors $O O$ in the ashpan, which can be opened and closed from the foot-plate by the handle $\mathrm{H}$. The dross when set is friable, and not hard like ordinary clinker ; and the grate is kept clean by putting the bars in motion occasionally for about ten seconds at a time. Fire cleaning during a journey is thus dispensed with, and the firing of the engines by men of ordinary powers of endurance is rendered practicable. The meehanism is simple and durable; and its introduction has rendered practicable the efficient working of the traffic on an exceptionally heavy line, with the inferior coal, containing 29 per cent. of dross, which crops out on the western boundary of the Cape coalfield.

Extent of Working.-The length of line now worked with colonial coal amounts to 280 continuous miles of main line and 12 miles of branch line. In its general features the line is extremely undulating, with a ruling gradient of 1 in 40, and a minimum radius of curvature freely used of 5 chains ( 330 feet); the highest elevation attained above sea level is 5,420 feet. The gross load taken by the engines is 102 tons, exclusive of the engine itself. An analysis made in Cape Town furnishes the following particulars as to the quality of the coal:- specific gravity, 1.48; volatile constituents, $15 \cdot 32$ per cent.; coke, 86.68 per cent.; ash, 29 per cent. The price of the coal at the Stormberg mines is 148 . per ton; at the Indwe mines, which are not yet accessible by rail, the price is $7 s$. per ton. 


\section{Discussion.}

Professor Alexander B. W. Kennedy, Vice-President, suggested that in the analysis of the coal, given at the end of the paper, the percentage of the volatile constituents ought to be 13.32 instead of $15 \cdot 32$, or else that the percentage of coke ought to be $84 \cdot 68$ instead of 86.68 ; because then the volatile constituents and the coke would add up to 100 , as he presumed ought to be the case. The ash he supposed was all included in the coke.

Mr. William Galloway, having made the special report on the Stormberg and Indwe coalfields, referred to in pages 113 and 114 of the paper, mentioned that the part of the coalfield over which he had travelled extended from the neighbourhood of Molteno, Fig. 1, Plate 32, past the Indwe mines, for a distance of fifty or sixty miles towards the north-east. The outcrop of the coalfield, as described by Mr. Dunn and some other geologists who had examined it, extended from the Molteno mine up through the Orange Free State into the Transvaal. Thence it stretched towards the north-east, and turning back southwards passed along the western boundary of Swaziland, and kept more or less parallel to the east coast, until it reached the Indwe mines, and then turned westwards to Molteno. The Indwe and the Molteno mines were at the outcrop. At present indeed the coal was known only at the outcrop. No shafts had as yet been sunk in any part of the coalfield, except in the Transvaal and in Natal, where some few shallow shafts had been sunk lately. The mining was of a very rudimentary character, so far as it had been pursted.

One of the first things that struck any one accustomed to the coalfields of England and the continent was the regularity of the strata in the Cape coalfield; the hill sides were entirely free from deposits of earthy matter, with the exception that between the beds of hard rock there were short slopes of débris; but the hard rocks themselves stood out exposed to view everywhere along the hill sides, presenting a very peculiar appearance. On observing 
(Mr. William Galloway.)

those rocks from a distance of a few miles, it was seen that they lay almost perfectly horizontally, that there were no contortions, and that there were few dislocations of any kind. The coal measures were included between red rocks which lay above them, known locally as the Red Beds; and red, buff, and mottled rocks which lay below them, and were locally called "Karroo." In this respect they resembled to some extent the Coal Measures of England, where there were also red rocks above and below; and the appearance of the Cape beds would almost lead to the supposition that they were similar in age to the English Coal Measures. Geologists who had examined them of late years were coming he believed to the conclusion that they nearly corresponded with the English Coal Measures; and he had recently been told that some fossils had been found which tended to prove that this was the case.

The coal measures were only about 1,000 feet thick in Cape Colony-a small thickness when compared with those of the Welsh coalfield, which were about 12,000 feet thick in the thickest part. Furthermore in Cape Colony there was only one seam of coal of any consequence in that thickness of 1,000 feet. That one seam of coal towards the west contained 22 or 23 inches of good coal; and eastwards, towards the Indwe mines, it contained about 4 feet or a little more. It bore the same character throughout, consisting of alternate beds of coal and shale, the latter varying from perhaps 15 or 18 inches down to 8 or 9 inches, and the coal beds from 3 inches up to 2 feet 2 inches, none of them being thicker than 2 feet 2 inches. Those shale beds would be considered a source of trouble and expense in England; but inasmuch as the seam contained the same shale beds throughout its whole extent, the conditions were identical in this respect in the different mines. The roof of the seam was remarkably good as a rule, consisting of hard sandstone. One peculiar feature of the South African coalfield was that it was intersected by volcanic rocks to an enormous extent. There was no parallel to it in Europe that he was aware of. The whole country was seamed through with dykes and horizontal sheets of the basalt rock "dolerite." In riding along the edge of the coalfield, sometimes for ten or fifteen miles, no outcrop of coal could be found, the whole 
being hidden by masses of volcanic rocks; and the scenery of the whole country owed its peculiar appearance to those volcanic rocks. The dolerite had rendered the coal anthracitic in every part where it approached the seam; and had thus made it practically useless for any purpose at present known, on account of the large percentage of ash, to which Mr. Stephens had referred.

The analysis of the coal having been given in the paper, he would only amplify that portion of the subject by saying that part of the mission which he had had to perform for the colonial government had been to test the relative qualities of the coal from two different areas of the coalfield, namely Molteno and Indwe; and also to compare them with those of Welsh coal. For that purpose he had spent about a week on a locomotive with a loaded train, the whole amounting to 142 tons; and had run the train between East London and Blaney, a station about thirty miles up the railway, on which there were heavy gradients, the rise altogether amounting to about 1,000 feet; the train was run from East London and back, once and sometimes twice in a day. The result of the trials showed that, on the locomotive employed for these tests, Welsh coal evaporated $8.76 \mathrm{lbs}$. of water per lb. of coal; Indwe coal, which was that from the mine furthest to the east, evaporated $5.62 \mathrm{lbs}$; and Molteno coaI evaporated 5.04 lbs. These were the results of a number of trials with the different kinds of coal. The locomotive was fitted with Mr. Tilney's movable fire-bars, as described in the paper; and he could bear testimony to their great efficiency, and to the great saving of labour to the firemen in consequence of their use. The locomotive had a fire-brick arch in the front end of the fre-box, as shown in Plate 34; and before commencing the trials he had another arch put in at the back end just over the door, sloping down to within about 15 inches of the front arch, so as to deflect the air that was admitted at the door down on to the top of the fire. His experience had been that with the great amount of ash produced by the coal the draught up through the fire-bars was very weak; and as a consequence a great deal of the combustible matter escaped up the chimney unburned, producing vast clouds of smoke. In order to avoid that waste, he had caused the fire-doors to be opened to a greater 
(Mr. William Galloway.)

or less extent according to the condition of the fire at the moment, whereby some considerable saving of fuel had been effected.

The length of railways now opened in the colony was as follows. On the eastern system 292 miles, from East London up to Aliwal North; on the midland system up to De Aar, including the branches to Graaff Reinet, Port Alfred, and Colesberg, 633 miles; on the western system up to Kimberley, including the branches near Cape Town, 774 miles. As yet colonial coal was used only on the eastern system; and one of the great objects of the government in having the coalfields surveyed was to ascertain whether there was likely to be sufficient coal for supplying the railways for a certain number of years, as it was contemplated to make a railway across between the eastern system and the midland, through a country which would not pay for the construction of a railway. That junction line would be made principally for the purpose of carrying coal across from the eastern to the midland and -western systems. There was also an intention of making another railway, 58 miles long; to connect the Indwe mines with the eastern system, so that the Indwe coal might be brought on to the eastern railway, and might perhaps to some extent replace the thinner and rather less economical coal worked at Molteno. From the Indwe mines the railway was further intended to pass by Molteno across to Middelburg on the midland line; and the coal was then expected to travel northwards up to Kimberley, and southwards down towards Cape Town, over the western line.

Having been asked to report on that part of the question also, he had made calculations to ascertain how far the colonial coal could compete with English coal. Taking English coal at $36 s$. per ton delivered at Cape Town, which was about the price when he was there, and colonial coal at 5s. per ton at the Indwe mines, he had Inade out that the colonial coal could travel down towards Cape Town-taking the railway carriage at 0.625 penny per ton per mile, which was the lowest rate that the general manager could allow-to within about 340 miles of Cape Town, and would there be as economical as Welsh coal; but not further. Welsh coal being so much better in quality, although so much dearer, was able to 
travel up to a distance of about 340 miles from Cape Town to meet the colonial coal. Of course the present higher price of Welsh coal would now alter that calculation to some extent, and enable the colonial coal to compete with it down to a point still nearer to Cape Town. The saving by the use of Indwe coal over the whole of the colonial railways he had estimated at $£ 58,000$ a year.

Mr. H. W. WhIтE said that in 1879 he had tried a sample of Natal Newcastle coal at the Cape of Good Hope dockyard. It was only a small trial, the whole quantity being no more than about 4 tons; and the coal itself had the appearance of coming from near the outcrop. The result was fair, the evaporative effect being nearly 70 per cent. of that of the mixed English coal then generally used in the dockyard. The quantity of ash and clinker was rather large, but not more than might be expected in coal from the outcrop. In 1882 the price of English steam coal at Cape Town went up to $£ 6$ a ton; and 23 miles from Cape Town, at Simon's Town, where he was at the time, it was $£ 7$ a ton, and very little was to be had at that price, owing to a war scare. The advantage of having coal in the colony was therefore obvious, both from the merchants' point of view and also from that of the colonial steam-users, a class now becoming numerous and important. At that time a large proportion of the steam used in the colony was raised from wood, and sometimes from cow-dung when wood could not be got: in fact from anything that could be burnt.

With regard to the arrangement of the movable fire-bars described in the paper, he thought possibly the serrations on the bars might be somewhat too fine to be durable; and also that the driving gear for actuating the bars would be rather apt to slip whenever they struck into a particularly hard piece of clinker.

The President asked whether the colonial coal had been used at all for marine purposes, to which an allusion was made in page 113 of the paper.

Mr. White replied that the Indwe coal was used in steamers calling at the port of East London. Tugs and such steamers used it 
(Mr. H. W. White.)

almost entirely, and satisfactorily : that is, for coasting and towing purposes.

The President asked how the large amount of einder or dirt was got rid of on shipboard.

Mr. White replied that the furnace of a marine boiler could be much more easily dealt with in cleaning the fires than the fire-box of a locomotive. It was on a fair level with the fireman, and if once he could bring the clinkers up from the bars there was no difficulty in pulling them out. There was of course a considerable amount of work in sending so much more ashes overboard, but that was all.

Mr. StepHens wrote that the serrated fire-bars lasted considerably longer with the colonial coal than the plain fire-bars did with the Welsh coal, because the dross from the colonial coal protected the serrations from the action of the incandescent coal. In the preliminary trials the bars had been moved by an eccentric, for which the frictional driving gear had been substituted in order to obviate the chance of breakage in the event of the motion being checked by hard clinker; but the quantity of hard clinker formed was so small that it gave no trouble, and the friction gear did not slip (page 121) unless oil got on the drums.

The consumption of Stormberg coal per train-mile was slightly more than double that of the best Welsh steam coal. The consumption of the coal from the Indwe mines was about 60 per cent. in excess of Welsh.

The Indwe coal used in the tug steamers in the port of East London was found to answer very well, even when disabled ships had to be towed to Port Elizabeth, a distance of 150 miles. No attempt to use it on a long royage had yet been made.

Mr. JERemran Head, Past-President, asked whether any attempt had ever been made to wash the colonial coal. Such good results had been obtained in the north of England and elsewhere from washing dirty coal, whereby the ash was reduced from 15 or 16 per cent. down to 
5 or 6 , that the most obvious way to deal with this colonial coal in the first instance would seem to be to wash it, which could now be done at a small expense both of labour and of water. Also had any attempt been made to coke the coal ?

Mr. Galloway replied that no attempt had yet been made to wash the coal. The coal as used was in lumps, which did not contain any visible earthy matter; consequently washing would not be of so much use as careful hand-picking. Recently he had sent out drawings for a small hand-washing machine to Mr. Stephens, who was anxious to wash the small coal; but beyond this nothing had yet been done. Some attempts to coke the coal had been made he believed on a small scale at East London by Mr. Tilney; but he had not succeeded in making coke that would be suitable for any purposes.

Mr. WHITE added that the probable reason the coal had not been washed was the want of water, a want which made itself felt in many industries in Cape Colony to an extent hardly realised in this country.

Mr. Wirliam SchöNHeyder asked whether, when the experiments were made with Welsh coal in the locomotive, it had proper fire-bars suitable for Welsh coal; or whether the same bars were used that were employed for the colonial coal.

Mr. Galloway replied that Mr. Tilney's serrated fire-bars were taken out for the experiments with the Welsh coal, and ordinary bars were substituted. It would be noticed from the drawings however that the locomotive had a relatively large fire-box, much larger in proportion than the fire-box nsed in England; and consequently the Welsh coal might not have been tried under as advantageous circumstances as it would have been in a smaller fire-box.

Mr. Conber Woodalu mentioned that in the north of Natal coal was now worked extensively. Two years ago it was being opened 
JLS. 1890.

(Mr. Corbet Woodall.)

rapidly in Natal, and the railway was being carried forwards from what was then the terminus at Lady Smith towards Dundee and Newcastle, so as to bring the coal down to the port at Durban. The railway was not of a kind suitable for developing traffic of that sort rapidly, because it contained a great number of long gradients of 1 in 32 ; and the bridges crossing the valleys were of such a slight build that the train had to be pulled up in order that a man might get on and go across the bridge with it, so as to ensure that it should not go across faster than at a certain slow speed; then the man waited for the return train, mounted it, and went back again. The curves also were extremely sharp. The coal in Natal was much superior to that now described as worked in Cape Colony; and he had no doubt that, when the railway facilities were improved, it would be brought down to Durban and the east coast, not only for locomotive purposes, but also for the working of the coasting steamers. In the samples which he had brought home of the Natal coal the ash did not exceed 12 per cent. He had tested them for gas-making, and had found that for this purpose they were nearly equal to coal from the Durham coalfield. Mr. Galloway had referred (page 117) to the rudimentary mode of working the colonial coal; and allusion had been made in the paper (page 113) to the cost of transit by ox-wagon or "trecking." At one colliery that he had visited he had been lowered by an ox, which backed to let him down, and went forwards to pull him up; and that was the way in which the coal was raised from the pit. The method of carrying by ox-wagon was so crude, and so cruel to the oxen, that it was impossible to carry heavy loads except at an enormous cost. The drivers of the teams of oxen, called transport riders, were all Boers, and they used stones to scotch the wheels for resting the oxen in going up hill; but he had never seen them move any stones out of the way, whether deposited by themselves or by anyone else. At the best the roads were bad enough, and in this way they were made still worse.

Mr. William B. TRIPP said he had read the former reports on the colonial coal by geologists and others, and had understood from them that it was of a different character from the English coal, the latter 
being supposed to have been formed on the site where the plants composing it had formerly grown; while colonial coal was supposed to have been brought down by water, and deposited in conjunction with earth, sand, and other matters; and this supposition would to a large extent account for the amount of ash found in it. He should be glad to know whether Mr. Galloway considered all the colonial coal to be of this nature; or whether his more recent resenrches had shown it be of a different kind.

Mr. Galloway replied that he was at issue with many geologists in regard to the deposition even of English coal ; and in this respect he was not alone. During recent years some eminent French mining engineers* had led a revolt against the ordinary method of explaining the presence of coal in the Coal Measures; and had declared that all the indications tended to show that coal was deposited from water like other sedimentary strata, and had not grown in sitú. Having himself carefully investigated the subject under ground, where all the beds could be seen much better than a field geologist could see them on the surface, he had long been of the opinion which he had expressed $\dagger$ at various times and in his report to the government of Cape Colony, that the English and all other coal beds had been deposited in the same way as the African coal beds, and that they were all subaqueous. That other mining men of this country were of the same opinion had been shown by some recent papers which had been sent to him; only a few days ago he had received one by Mr. Hall, the President of the Manchester Geological Society, and another by Mr. A. R. Sawyer, one of the Inspectors of Mines. The question was one which, although it had not yet received much

* Mémoire sur la formation de la Houille, par M. C. Grand' Eury. Annales des Mines, tome 1, 1882, page 99.

Études sur le terrain houiller de Commentry, par MM. Ch. Brougniart, H. Fayol, Do Launay, S. Meunier, Regnault, Sauvage, et Zeiler. Bulletin de la Société de l'Industrie Minérale, tome xv, 1886.

+ On the Mode of Occurrence of Coal. Transactions of the Cardiff Naturalists' Society, 1885. 
(Mr. William Galloway.)

attention in this country, would probably be soon brought to the front.

Professor KenNedy considered it would add to the value of the present discussion if some analyses were furnished of the coals to which reference had been made.

Mr. Galtoway said the analyses of the coals he had described were contained in his report to the Cape government, and he should be happy to furnish copies of them. (See page 128.)

The PRESTDEN said the southern portion of Africa was a region of great importance to this country, being so largely British territory; and the elucidation of the various points which had been brought out in the discussion was a valuable addition to the paper itself.

With reference to the fire-bars used for burning Welsh coal in the locomotive trials made by Mr. Galloway (page 119), he thought that the result obtained, namely $8.76 \mathrm{lbs}$. of water per lb. of coal, clearly indicated that the bars had been spaced properly for burning Welsh coal. That result was what could be got in locomotives on any English railways with the ordinary temperature of $50^{\circ} \mathrm{Fahr}$. for the feed-water. The evaporation of 5.62 lbs. of water per lb. of the Indwe coal was about the average that would be got with Newcastle coal worked in a locomotive engine, even when used as large coal. Therefore there must be some elements in the Indwe coal which, were it not for the dirt, would make it much better for locomotive purposes than even English north-country coal. The lower evaporation of only $5.04 \mathrm{Ibs}$. of water per lb. of the Molteno coal was exceptionally bad, and would only be expected from coal that gave off smoke like a steam-tug all the year round.

The development of the large coalfields in South Africa would of necessity be a great advantage to England. If it was not an advantage to the coal-owners in England, it would undoubtedly be an advantage to the British traders and colonists, who had at present to buy coal at about $£ 5$ per ton at Cape Town; and the ship-owners who had to 
pay that price for their coal were now compelled to get more freight, in order to render their voyages profitable. The coalfields being situated within the Cape Colony, their development could not fail to prove an advantage to the empire. Moreover there could not be much doubt that, as the coal was worked inwards from the outcrop, the 29 per cent. of ash would become largely diminished. Having himself had something to do, not with working, but with using coal from the outcrops of the English coalfields, he had always found that, even when burnt in a house fire, coal from the outcrop left a large residue of ash.

As to washing the coal, he thought it would not pay to break up the coal containing 29 per cent. of ash, and then wash it and convert it into coke. It seemed doubtful to him whether it would coke at all, or whether in that respect it would not be much like the ordinary Welsh steam coal. He should not expect to get more than about 60 per cent. of coke out of it; and that coke would in his opinion be of a friable nature, as in the case of coke obtained from Welsh steam coal. The arrangement mentioned in the paper for working the locomotives with this coal he therefore thought was the only feasible one; and if Mr. Stephens could keep up steam with the present $1 \frac{1}{2}$-inch spaces between the fire-bars, and not leave a fire trail behind, such as he had spoken of with the 3-inch spaces, he was going in the right direction; and the probability was that he would devise some plan by which he wonld succeed in reducing the $1 \frac{1}{2}$-inch space still further, and get rid of the dirt before it reached the glutinous state in which it adhered to the fire-bars. Before it got vitrified he believed it would fall down, and conld then be got rid of through narrower spaces.

In now moving a vote of thanks to Mr. Stephens for his paper, he would couple with it a request that in the course of a year or two, when the workings had got into the hill, and solid coal had been won at a sufficient distance from the outerop, he would supplement the present paper by describing the further results then obtained.

Mr. Wirtiam Gatlowax sent the following further information respecting the colonial coal, as promised in page 126. 
(Mr. William Galloway.)

Analyses of Coal in Cape Colony, extracted from a report upon the Coal Deposits of the Indwe Basin and Stormberg range of mountains, by W. Galloway, Mining Engineer, 1889. Bluebook [G. 50, 89].

1. Indwe Mine.-Analyses of the three upper beds of the seam, by Dr. Hahn :-

\begin{tabular}{|c|c|c|c|c|c|}
\hline $\begin{array}{c}\text { Position } \\
\text { in the seam. }\end{array}$ & $\begin{array}{l}\text { 'Thickness } \\
\text { of Bed. }\end{array}$ & $\begin{array}{l}\text { Specific } \\
\text { Gravity. }\end{array}$ & $\begin{array}{c}\text { Volatile } \\
\text { Constituents. }\end{array}$ & Coke. & Ash. \\
\hline Top & $\begin{array}{c}\text { Inches. } \\
11\end{array}$ & $1 \cdot 26$ & $\begin{array}{c}\text { Per cent. } \\
19 \cdot 57\end{array}$ & $\begin{array}{c}\text { Per cent. } \\
80 \cdot 43\end{array}$ & $\begin{array}{c}\text { Per cent. } \\
11 \cdot 08\end{array}$ \\
\hline Middle & 25 & $1 \cdot 48$ & $15 \cdot 32$ & $86 \cdot 68$ & $28 \cdot \$ 7$ \\
\hline Bottom & 11 & $1 \cdot 46$ & $17 \cdot 13$ & $82 \cdot 87$ & $24 \cdot 6 \tilde{\mathbf{5}}$ \\
\hline
\end{tabular}

Another analysis made by Dr. Hahn of coal from this seam: is as follows, but no details are given as to what part of the seam the sample was taken from:-

Specific Carbon. Hydrogen. Nitrogen. Sulphur. Oxygen.| Coke. Ash. \begin{tabular}{c|c|c|c|c|c|c|c} 
Gravity. & Per cent. & Per cent. & Per cent & Per cent. & Per cent. & Per cent. & Per cent. \\
1.587 & 61.021 & 3.208 & $2 \cdot 190$ & 0.434 & $2 \cdot 178$ & $75 \cdot 26$ & $30 \cdot 32$
\end{tabular}

In a trial made with Indwe coal by the writer, in a small steam boiler at Molteno, the residue amountedm) 37.6 per cent. In a trial made by Mr. Tilney in the furnace of a stationary boiler at East London, the residue amounted to 29 per oent.

2. Stormberg Coal, Molteno district-Two analyses Igiven 'in Professor Green's report, but not typical of the coal now being worked at Molteno, Cyphergat, and Fair View mines:-

\begin{tabular}{|c|c|c|c|c|c|c|c|}
\hline $\begin{array}{l}\text { Name } \\
\text { of } \\
\text { Farm. }\end{array}$ & $\begin{array}{c}\text { Thiokness } \\
\text { of } \\
\text { Coal. }\end{array}$ & $\begin{array}{c}\text { Thickness } \\
\text { of } \\
\text { Shale beds. }\end{array}$ & $\begin{array}{l}\text { Volatile } \\
\text { Matter. }\end{array}$ & $\begin{array}{l}\text { Coke } \\
\text { and } \\
\text { Ash. }\end{array}$ & Moisture. & Ash. & Sulphur. \\
\hline & Ft. ins. & Ft. ins, & Per cent. & Per cent. & Per cent. & Per cent & Per cent \\
\hline Van Zyls & 21 & 12 & $10 \cdot 31$ & $89 \cdot 69$ & $1 \cdot 13$ & $28 \cdot 80$ & 0.76 \\
\hline Vau Wyks & $111 \frac{1}{2}$ & 12 & $9 \cdot 22$ & $90 \cdot 78$ & $1 \cdot 77$ & $22 \cdot 34$ & 0.97 \\
\hline
\end{tabular}


In trials made by the writer in the furnace of the same small steam boiler at Molteno, the residue after combustion of samples of coal obtained from the three principal mines near Molteno was :Molteno $36 \cdot 6$ per cent., Cyphergat $36 \cdot 2$ per cent., Fair View $42 \cdot 6$ per cent. The obvious reason why the quantity of ash is necessarily greater in practical trials than by analysis is that in the former case some of the carbon remains unconsumed, even with the most careful stoking.

Mr. StePhens wrote from Cape Town that since the reading of the paper he had returned from a visit to the Natal Government Railways; and having availed himself of the opportunity to inspect the mines there in operation, he could more than confirm Mr. Woodall's remarks (page 124) concerning the Natal coal, none of which resembles the Indwe or the Stormberg coal. It is almost entirely free from ingrained sand, which is the drawback to the Indwe coal; it makes steam very rapidly, and is preferred by experienced engine-drivers to the South Yorkshire coal, which it will have superseded there in a few months.

The author's visit was made for the purpose of reporting on the performance of some engines of exceptional weight and power, which are being introduced on the Natal Railways. Their unqualified success he considers is largely due to the ease with which the Natal coal maintains steam at full pressure up the longest inclines on a line with a ruling gradient of 1 in 30 and with curves freely used of 300 feet radius, notwithstanding a moderate grate-area and an ashpan much contracted by two axles underneath it.

The first mine adjoining the railway is at Elands Laagte station, 205 miles from the seaport of Durban, and the last is at Newcastle, 269 miles from Durban: in addition to which the coal seams crop out in the cuttings and watercourses for about 20 miles further along the extension of the railway now in progress from Newcastle to the Transvaal border viâ Laings Nek, where a tunnel is being made. The coalfield through which the railway runs is thus about 80 miles long; but the continuity of the coal is broken by dolerite, as described by Mr. Galloway (page 118), though not to the same; extent 
(Mr. Stephens.)

as in the Cape Colony. No attempt has yet been made to ascertain the width of the coalfield, the quantity of coal adjacent to the railway being to all appearance enough to supply the requirements of South Africa for many generations.

The Elands Laagte mine, from its proximity to the former terminus of the railway at Lady Smith, was the first to be extensively worked, and the early deliveries contained much shale and sulphur. It was probably from this source that the coal was supplied for the trial made by Mr. White in the dockyard at Simon's Town in 1879 (page 121).

The railway to Dundee, referred to by Mr. Woodall (page 124), has recently been opened, and the Dundee Coal Company have contracted for the Natal Railway supply. The seam worked is $4 \mathrm{ft}$. 6 ins. thick, and is perfeetly clean. One of Messrs. Rennie's line of steamers, which trade from London to Natal, recently took 350 tons of this coal, and made a successful voyage; and a further order has been given. At Newcastle, 38 miles further north, there is nearly seven feet thickness of coal in three seams, with two partings of shale in which the holing is made. The trials made have shown. this to be excellent steam coal, and being fairly hard it will bear transport well.

When the extensions now in progress of the Cape and Natal Railways to a point of junction in the Orange Free State are completed, the Natal coal will in all probability be used to work the upper sections of the Cape Railways; but the Indwe mine, from its proximity to the eastern system and to the projected extensions, will supply that portion of the Cape Railway system.

The author regrets that Mr. Galloway was compelled to return to England, withont visiting the Natal coalfield as was originally intended.

The percentage of the volatile constituents in the coal, of which the analysis is given in page 116 of the paper, shorld be 13.32 he believes, as pointed out by Professor Kennedy (page 117), instead of $15 \cdot 32$ per cent. 


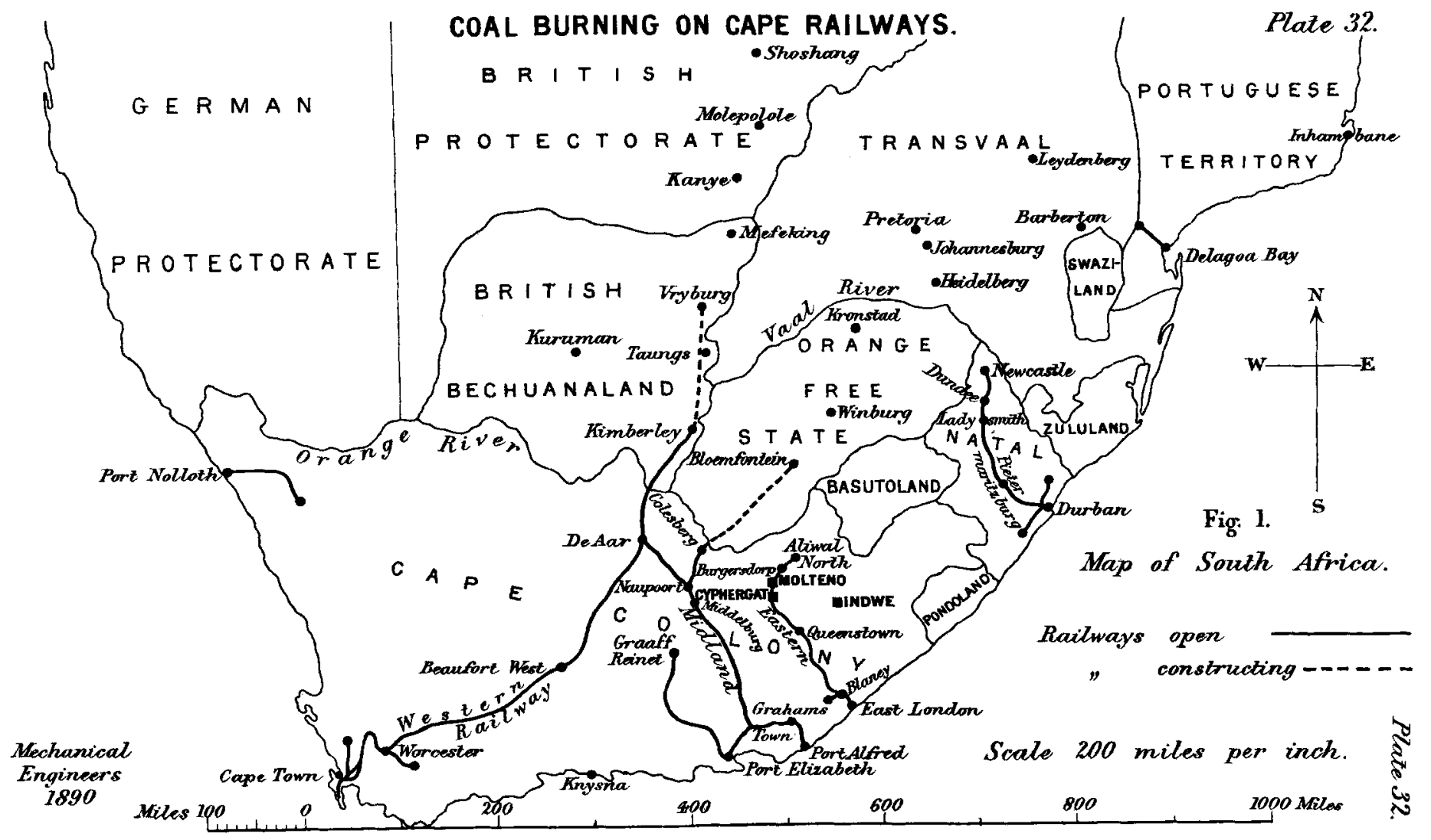



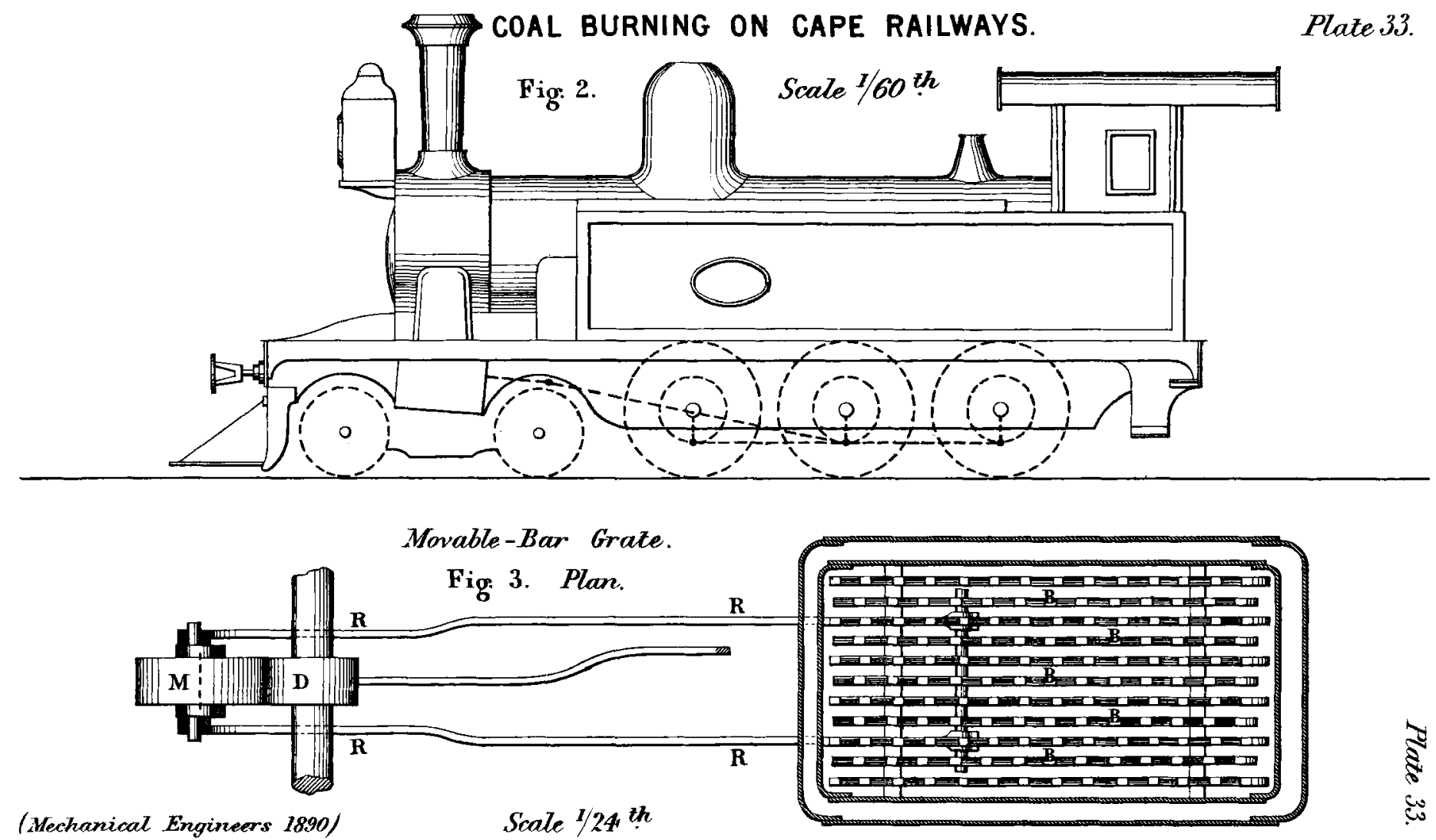
Movable-Bar Grate. Fig: 4. Longitudinal Section.

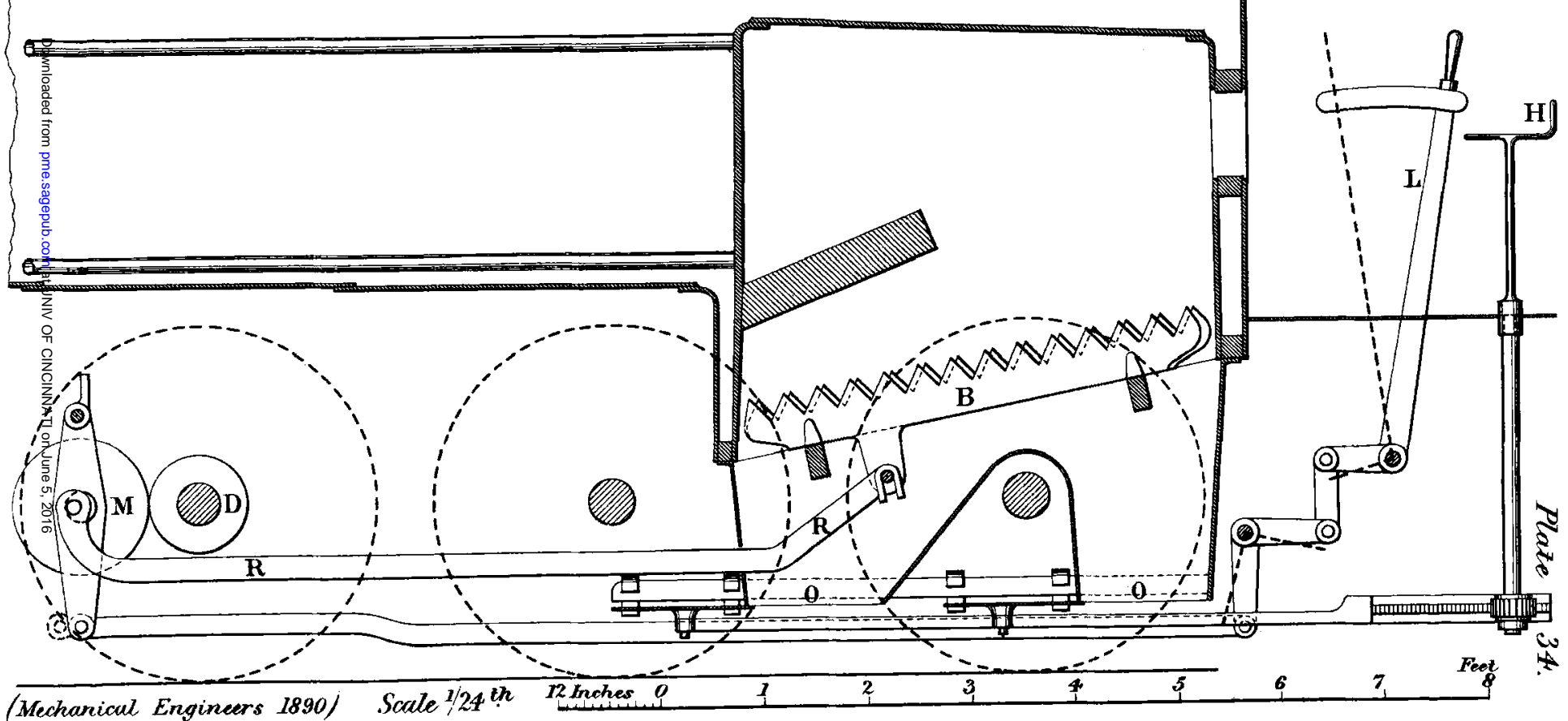

